\title{
Biofertilizer, a way towards organic agriculture: A review
}

\author{
Ritika Bhattacharjee* and Utpal Dey \\ Department of Plant Pathology, Vasantrao Naik Marathwada Agricultural University, Parbhani - 431 402, Maharashtra, \\ India.
}

Received 20 September, 2013; Accepted 19 May, 2014

\begin{abstract}
Fertilizers supply essential plant nutrients, mainly nitrogen $(\mathrm{N})$, potassium $(K)$ and phosphorous $(P)$. These fertilizers increase the yield of the crop but they cause several health hazard. Due to the several health hazard, consumer preferences shift towards the use of the organic food grown without use of any chemical. In recent years, biofertilizers have emerged as an important component for biological nitrogen fixation. They offer an economically attractive and ecologically sound route for providing nutrient to the plant. Biofertilizers are low-cost renewable source of nutrient that supplements the chemical fertilizer. Biofertilizers gained importance due to its low cost amongst small and marginal farmer.
\end{abstract}

Key words: Biofertilizer, isolation, mass multiplication, $\mathrm{N}_{2}$ fixers, plant growth promoting rhizobacteria (PGPR), organic agriculture.

\section{INTRODUCTION}

The term biofertilizer, represent everything from manures to plant extracts. "Biofertilizers" are those substances that contain living microorganisms and they colonize the rhizosphere of the plant and increase the supply or availability of primary nutrient and/or growth stimulus to the target crop. There are numerous species of soil bacteria that colonize mainly in the rhizosphere of plants. These bacteria are collectively known as plant growth promoting rhizobacteria (PGPR). Some PGPR promote the growth by acting as biofertilizer. Microorganisms mainly nitrogen fixer, phosphate solubilizer and mycorrhizae are the main sources of biofertilizer. The microorganisms used for the biofertilizer are bacteria of Bacillus, Pseudomonas, Lactobacillus, photosynthetic bacteria, nitrogen fixing bacteria, fungi of Trichoderma and yeast. Biofertilizers have shown great potential as a, renewable and environmental friendly source of plant nutrient. Biofertilizers are ready to use and used as a live formulation of beneficial microorganisms, when it amended to seed, root or soil, it mobilizes the availability and utility of the microorganisms and thus improves the soil health. In general, bio-fertilizers are microbial preparations containing living cells of different microorganisms which have the ability to mobilize plant nutrients in soil from unusable to usable form through biological process. Bio-fertilizers are used in live formulation of beneficial microorganism which on application to seed, root or soil, mobilize the availability of

*Corresponding author. E-mail: ritu45880@gmail.com.

Author(s) agree that this article remain permanently open access under the terms of the Creative Commons Attribution License 4.0 International License 
Table 1. Carriers.

\begin{tabular}{lccc}
\hline Form & Liquid & Powder & Granular \\
\hline Appearance & Without strange smell & Brown & Brown \\
Fast-growing Rhizobium & $>0.5 \times 10^{9} / \mathrm{ml}$ & $>0.1 \times 10^{9} / \mathrm{g}$ & $>0.1 \times 10^{9} / \mathrm{g}$ \\
Slow-growing Rhizobium & $>1.0 \times 10^{9} / \mathrm{ml}$ & $>0.2 \times 10^{9} / \mathrm{g}$ & $>0.1 \times 10^{9} / \mathrm{g}$ \\
N fixing bacteria & $>0.5 \times 10^{9} / \mathrm{ml}$ & $>0.1 \times 10^{9} / \mathrm{g}$ & $>0.1 \times 10^{9} / \mathrm{g}$ \\
Si bacteria & $>1.0 \times 10^{9} / \mathrm{ml}$ & $>0.2 \times 10^{9} / \mathrm{g}$ & $>0.1 \times 10^{9} / \mathrm{g}$ \\
Organic P & $>0.5 \times 10^{9} / \mathrm{ml}$ & $>0.1 \times 10^{9} / \mathrm{g}$ & $>0.1 \times 10^{9} / \mathrm{g}$ \\
In organic P & $>1.5 \times 10^{9} / \mathrm{ml}$ & $>0.3 \times 10^{9} / \mathrm{g}$ & $>0.2 \times 10^{9} / \mathrm{g}$ \\
Multi-strain bio-fertilizer & $>1.0 \times 10^{9} / \mathrm{ml}$ & $>0.2 \times 10^{9} / \mathrm{g}$ & $>0.1 \times 10^{9} / \mathrm{g}$ \\
\hline
\end{tabular}

nutrients particularly by their biological activity and help to build up the lost microflora and in turn improve the soil health in general (Ismail et al., 2014). Their mode of action differs and can be used alone or in combination. For easy application, biofertilizers are packed in suitable carrier such as lignite or peat. Carrier also plays an important role in maintaining sufficient shelf life (Singh et al., 1999).

Rhizobium is the most studied and important genera of nitrogen fixing bacteria (Odame, 1997). Azospirillum spp. contribute to increased yields of cereal and forage grasses by improving root development in properly colonized roots, increasing the rate of water and mineral uptake from the soil, and by biological nitrogen fixation (Okon, 1985). Biofertilizers have shown great potential as supplementary, renewable and environmental friendly sources of plant nutrients and are an important component of Integrated Nutrient Management (INM) and Integrated Plant Nutrition System (IPNS) (Raghuwanshi, 2012). Naturally grown biofertilizers not only give a better yield, but are also harmless to humans and lead to better sustainable economic development for the farmers and their country (Mishra and Dash, 2014).

\section{ISOLATION TECHNIQUES}

\section{Isolation technique for Rhizobium spp.}

Intact root nodules from a healthy Sysbania exaltata plant were selected. One of the pink juvenile root nodule was selected and transferred to a drop of sterile water in a Petri dish. The nodule in the drop of water was crushed in between two glass slides causing the release of nitrogen fixing Rhizobium bacteria into the drop of sterile water. The smear of the crushed root nodule was streaked onto yeast extract mannitol agar (YEMA) plate with 1\% Congo red dye. The culture was then incubated at 20 to $25^{\circ} \mathrm{C}$ for three days (Boraste, 2009).

\section{Isolation technique for Azospirillium spp.}

Juvenile root from a healthy sugar cane plant was taken and kept in saline for $5 \mathrm{~min}$. With a forceps, root was immersed to a semisolid Bromothymol blue medium broth containing $0.8 \%$ agar in a test tube and incubated at 20 to $25^{\circ} \mathrm{C}$ for at least a week. A loopful of culture adjacent to the root in the broth was transferred to bromothymol blue media plates. The culture was incubated at 20 to $25^{\circ} \mathrm{C}$ for at least a week.

\section{Isolation of phospho bacteria from the rhizoids}

1. Soil samples: They are collected from the different agricultural land.

2. Serial dilution method: $10 \mathrm{~g}$ of soil sample is dissolved in the $100 \mathrm{ml}$ of distilled water and the sample is mixed well, and by dilution making the sample $10^{1}$. Then the soil sample in sterilized water is serially diluted up to $10^{7}$ dilution. Then $10^{5}, 10^{6}, 10^{7}$ dilution is taken into spread plate technique.

3. Spread plate technique: Nutrient agar are poured in to the plate, after solidification of medium $0.1 \mathrm{ml}$ of medium are poured into the agar medium plate, then they are incubated at $37^{\circ} \mathrm{C}$ for $24 \mathrm{~h}$.

\section{Carriers}

Carriers (Table 1) increase the effectiveness of the biofertilizer. It enables easy handling and increases the storage or shelf life. Carriers which are used for making solid type of biofertilizer products are clay mineral, diatomaceous soil, and white carbon as mineral; rice, wheat bran, peat, lignite, peat soil, humus, wood charcoal and discarded feed as organic matter. However, clay mineral and rice bran are most often used as carriers. To achieve the tight coating of inoculant on seed surface, use of adhesive, such as gum arabic, methylethylcellulose and vegetable oil is also available.

\section{MASS PRODUCTION OF BIOFERTILIZERS (FIGURE 1)}

\section{Criteria for strain selection}

Efficient nitrogen fixing strains is selected and then 
Isolation of microbes from the soil

$\uparrow \downarrow$

Laboratory screening of microbes for plant growth

$\uparrow \downarrow$

Greenhouse screening of microbes to promote growth in potted soil

$\uparrow \downarrow$

Field screening of most effective microbes in cropped soil

(Crop variety and different soil types examined)

$\uparrow \downarrow$

Refinement of inoculum

$\uparrow \downarrow$

Production of biofertilizer

Figure 1. Production of biofertilizers.

multiplied on the nutritutionally rich artificial medium before inoculating in the seed and soil.

\section{Culturing in the flask containing broth}

The isolated strain is inoculated in the small flasks containing suitable medium for inoculums production. Now, the carrier was autoclaved at $15 \mathrm{psi}$ at $121^{\circ} \mathrm{C}$ for 20 min. The culture broth was mixed with the carrier at $30 \%$, that is, for $1 \mathrm{~kg}$ carrier; $300 \mathrm{ml}$ of culture broth was used. The mixture was spread on a plastic sheet in a closed room for air drying. The biofertilizer was packed in sterile plastic air tight bags and stored. For large scale production of inoculums, culture fermenters are used.

\section{Quality control}

Like every product, the biofertilizers should also follow some standards. The inoculants should be carrier based, and it should contain $10^{8}$ viable cells per gram of carrier on dry mass basis within 15 days of manufacture. The inoculums should have a maximum expiry period of 12 month from the date of manufacture. The inoculants should not have any contaminant. The contaminant is one of the biggest problems faced by the biofertilizers industry. The pH of the inoculant should be 6.0-7.5. Each packet containing the biofertilizer should be marked with the information eg. name of the product, leguminous crop for which intended, name and address of the manufacturer, type of carrier, batch or manufacture no, expiry date. Each packet should also be marked with the ISI mark. The biofertilizer should be stored in the cool place and keep away from direct heat.

\section{Types of biofertilizer (Table 2) available}

1. Nitrogen fixing biofertilizer: Rhizobium, Azotobacter, Azospirillum, Bradyrhizobium.

2. Phosphorus solubilising biofertilizer (PSB): Bacillus, Pseudomonas, Aspergillus.

3. Phosphorus mobilizing biofertilizer: Mycorrhiza (Plate $1)$.

4. Plant growth promoting biofertilizer: Pseudomonas.

\section{Mode of action of biofertilizer}

They fix nitrogen in the soil and the root nodules of the legumes crop and make it available to the plant. They solubilise the insoluble form of the phosphate like tricalcium, iron and aluminium phosphate into the available form. They produce hormones and anti metabolites which promote root growth. They also decompose the organic matter. When biofertilizers are applied to the seed and the soil they increases the 
Table 2. Different types of biofertilizers.

\begin{tabular}{|c|c|}
\hline Biofertilizer & Microorganism \\
\hline Nitrogen fixers & $\begin{array}{lll}\begin{array}{l}\text { Azolla pinnata, Rhizobium spp., Azotobacter } \\
\text { chroococcum, }\end{array} & \\
\begin{array}{l}\text { Azospirillum } \\
\text { diazotrophicus, Derxia gummosa }\end{array} & \text { Acetobacter }\end{array}$ \\
\hline Phosphate solubilizers & $\begin{array}{l}\text { Bacillus circulans, Bacillus coagulans, } \\
\text { Torulospora globasa, } \\
\text { Pseudomonas fluorescens (siderophore), } \\
\text { Thiobacillus (SOM), } \\
\text { Aspergillus niger (avirulent), Trichoderma sp., } \\
\text { Paecilomyces sp }\end{array}$ \\
\hline Potash mobilizers & Bacillus spp., Pseudomonas spp. \\
\hline Zinc mobilizer & $\begin{array}{l}\text { Pseudomonas spp., Bacillus spp., Rhizobium } \\
\text { spp. }\end{array}$ \\
\hline
\end{tabular}

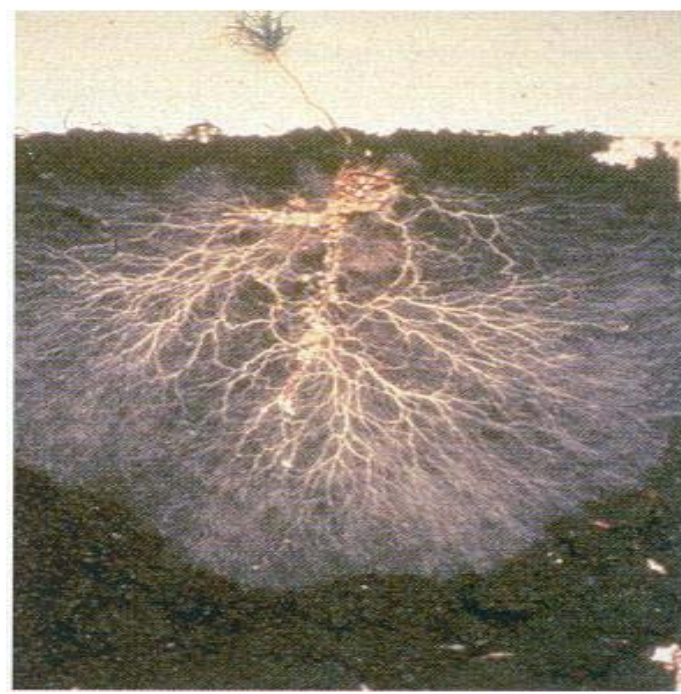

Plate 1. Mycorrhizae (Peters, 2002). containing tricalcium, iron and aluminium phosphate, hydroxy apatite, bonemeal, rock phosphate and some insoluble phosphate compound. The most efficient PSM belong to the genera Bacillus and Pseudomonas among bacteria and Aspergillus and Penicillum amongst fungi (Gaur, 1990). Several varieties of PSM have been isolated from the rhizospheric soil of the crop. Majority of bacterial organisms are known to solubilize phosphate. These bacteria and fungi are used as a biofertilizer. Their application in several crop tend to increase their yield in crop such as cereals, legume, vegetable, fruit crops (Kundu et al., 2009). Phosphate solubilising microorganisms release metabolite such as organic acid latter being converted into the soluble form (Nahas, 1996). Phosphate solubilising microorganisms dissolve soil $P$ through production of low molecular weight organic compound mainly gluconic and ketogluconic acid (Khan et al., 2009).

\section{Low cost medium preparation for PSB}

availability of the nutrient to the plant and increases the yield up to $10-20 \%$ without producing any adverse effect to the environment. Therefore, significantly increase the plant growth parameters viz., plant height, number of branches, number of roots, root length, shoot length, dry matter accumulation in plant organs and vigour index etc. (Ezz El-Din and Hendawy, 2010; Ateia et al., 2009; Mahmoud, 2009; Leithy et al., 2009; Gharib et al., 2008; Ismail et al., 2014).

\section{Phosphorus producing biofertilizer}

Phosphate solubilising microorganisms include several bacteria and fungi which can grow in the medium
Alternative for King's B broth (Pseudomonas spp.); 1. Fish extract, $10 \mathrm{ml}$; 2, Algal water, $25 \mathrm{ml}$; 3, Aloe vera extract, $5 \mathrm{ml}$; 4, Tap water, $100 \mathrm{ml}$; , pH, 7.2.

The broth was prepared, inoculated with $P$. flourescens and incubated at $27^{\circ} \mathrm{C}$ for $24 \mathrm{~h}$ on rotary shaker.

\section{Uses of PSB}

PSB can be used for all the crops including paddy, millets, oilseeds, pulses and vegetable.

\section{Method of application of PSB}

1. Seed treatment: $10 \mathrm{~kg}$ of normal size seeds of lentil, 


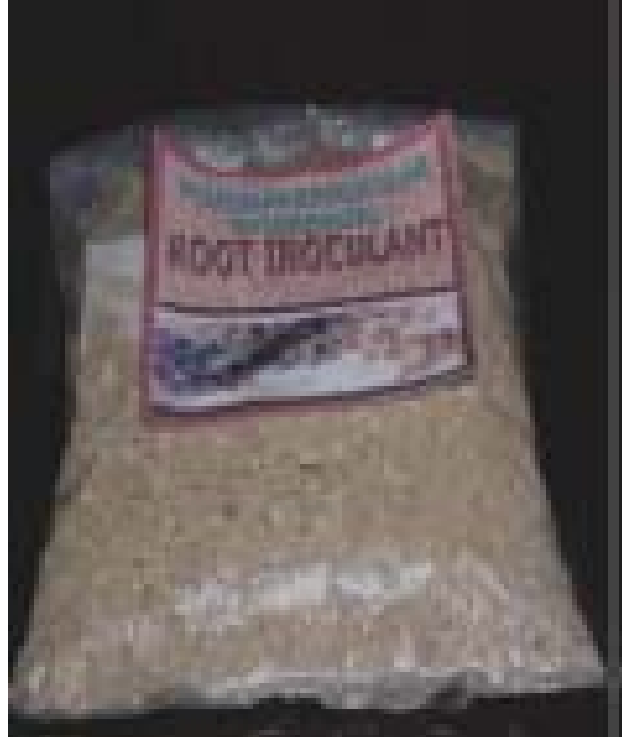

Plate 2. VAMRI.

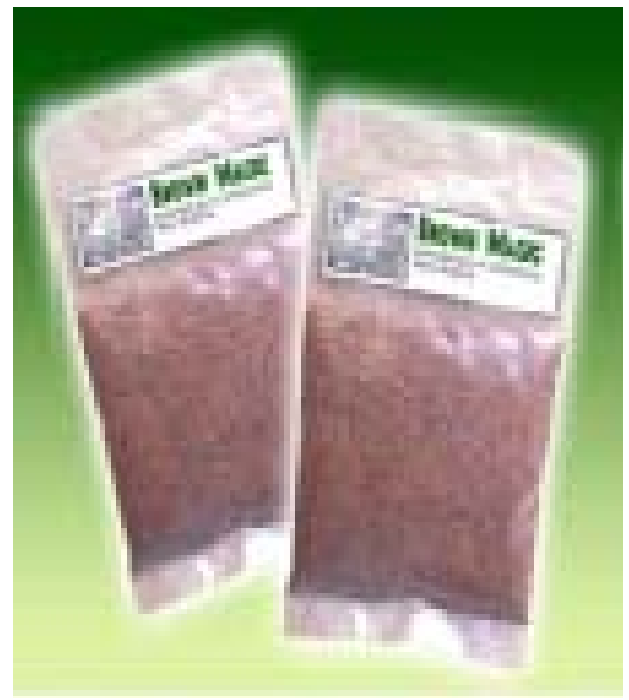

Plate 3. Brown magic.

mung, berseem treated with $200 \mathrm{~g}$ of PSB. Large size seeds like groundnut, chickpea, soyabean require 400$600 \mathrm{~g}$ inoculants for $10-12 \mathrm{~kg}$ seeds.

2. Seedling dip: This method is useful for the transplanted seedling and also useful for the vegetable crop. Inoculant suspensions are prepared in 1:10 ratio. Dipping the root of the seedlings in this suspension for $5 \mathrm{~min}$.

3. Soil application: $3-5 \mathrm{~kg}$ of inoculants is mixed with the $50 \mathrm{~kg}$ of farm yard manure (FYM).

Phosphorus deficiency is one of the major limiting factors in crop growth and nitrogen fixation in the tropical regions. Phosphorus requirement is next to the nitrogen. It makes up $0.2 \%$ of the body weight. It plays an important role in cell division, cell development, photosynthesis, breakage of sugar, nuclear transport within the plant. Nowadays, phosphorus is a non-renewable and costly input, and these phosphate fertilizers also have pollution problems associated with them. Mycorrhizal fungi (Plate 1) can utilize phosphorus from extremely low concentration. Mycorrhiza based biofertilizer technology is one of such successful technology capable of wasteland reclamation and beneficial in agriculture because it provides phosphorus nutrition to the plant. Mycorrhizae also benefit plants indirectly by enhancing the structure of the soil (Mahdi et al., 2010). AM hyphae excrete gluey, sugar-based compounds called Glomalin, which helps to bind soil particles, and make stable soil aggregates (Peters, 2002).

\section{Marketable product of mycorrhizal fungi}

Vesicular Arbuscular Mycorrhiza Root Inoculant (VAMRI) is a chopped dried corn roots infected with arbuscular mycorrhizal fungus, either Glomus mosseae or Glomus fasciculatum. VAMRI serves as bio-fertilizers and biocontrol agents of soil-borne diseases of different crops under various conditions. They show a degree of resistance or tolerance against soil-borne pathogens like nematodes, bacteria and fungi. VAMRI can substantially reduce or substitute the chemical fertilizer and pesticide requirements of crops. This inoculant can be used for pepper, eggplant, tomato, papaya, banana, pineapple, watermelon, onion, corn, sugarcane, peanut, fruit crops/trees and ornamental plants.

\section{Application}

VAMRI (Plate 2) can be applied by seed pelleting or coating for direct seeding crops, by mixing with the sowing medium .VAMRI can replace $50-100 \%$ of chemical fertilizers.

Brown magic is a mycorrhizal fungal inoculant that can be utilized as biological fertilizer and bio-control agent of root diseases of orchids. This fungus was selected from 200 isolates composed of sclerotium or fruiting bodies of fungi and mycelia collected and isolated from orchid roots.

\section{Application of brown magic (Plate 3)}

It increases the growth and survival of in vitro cultured orchid and it also increases the tolerance and resistance of plants to pathogens and diseases; induces early flowering and enhances the production of more suckers and longer spikes. This inoculant is environment-friendly, economical and easy to use. This inoculant is available at BIOTECH Sales office at UPLB. 

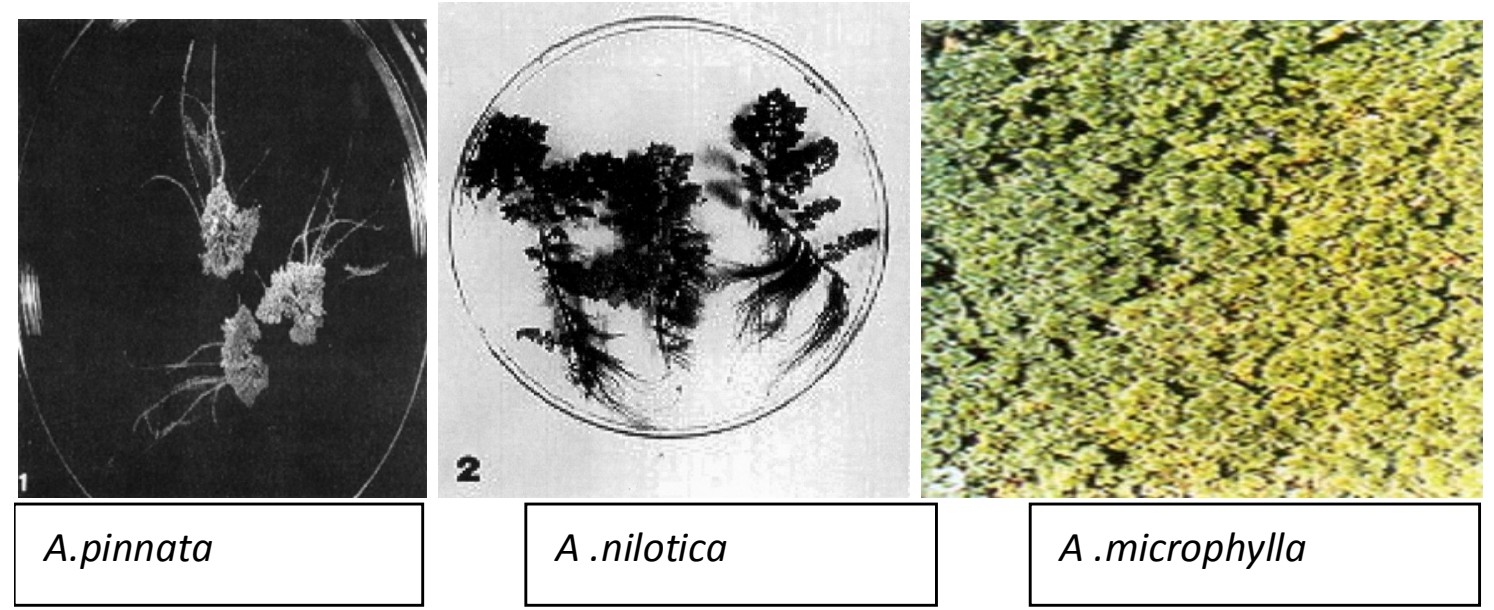

Plate 4. Different types of Azolla spp. (Pabby et al., 2004).

\section{Application of mycorrhizae}

Endomycorrhizae should be applied at a rate of $3,600,000$ propagules per Mycorrhizae via hand seeding, seed drilling, hydroseeding, broadcast and till, planting, or as a nursery medium.

\section{Facultative endophytic diazotroph (Azospirillum)}

Azospirillum belongs to family Spirilaceae. It is heterotrophic and associative in nature. It has also an ability to fix nitrogen of about $20-40 \mathrm{~kg} / \mathrm{ha}$, they also produce growth regulating substances. The different species of Azospirillum are Azospirillum amazonense, Azospirillum halopraeferens, Azospirillum brasilense. The Azospirillum form associative symbiosis with many plants particularly with those having the C4-dicarboxyliac path way of photosynthesis (Hatch and Slack pathway), because they grow and fix nitrogen on salts of organic acids such as malic, aspartic acid (Arun, 2007). It is mainly used for some recommended crops like maize, sugarcane, sorghum, pearl millet etc. Azospirillum species belong to the carbon compounds and adequately low level of facultative endophytic diazotrophs groups which colonize combined nitrogen (Andrew et al., 2007). Azospirillum, directly benefits plants by improving the fixing activity of bacteria in rhizosphere of plants (Nghia and Gyurjan, 1987). It helps in shoot and root development (Gonzalez et al., 2005).

\section{Obligate endophytic diazotrophs (Azotobacter)}

Azotobacter is an obligate aerobe, bacteria of the genus Azospirillum are a well-known or endocytobionts live in special cells of their hosts which are known as Rhizobia found in the root nodules of legumes or Frankia widespread in the soils of tropical, subtropical. Azotobacter as nitrogen-biofertilizer increase the growth and yield of various crops under field conditions (Table 3). These bacteria develop in close-legume symbiosis which is one of the most efficient fixing relationships with the roots of various wild plants (Doroshenko and Rawia, 2007; Rawia et al., 2009).

\section{Algal biofertilizers ( $\mathrm{N}$ fixers)}

\section{Azolla spp.}

It is a diazotrophic symbiont, it is well known for its utilization as a nitrogen fertilizer. Azolla spp. (Plate 4) float in water in large number and in soils where there is appropriate number of fern species. These are mostly found in the tropical and temperate ecosystems. There is a symbiotic association between Azolla and a cyanobacteria Anabaena. The host Azolla provide carbon source to the anabaena while its nitrogen requirement is fulfil by atmospheric nitrogen fixation by Cyanobacteria. It has the ability to fix atmospheric nitrogen through bacteria and the infection always occurs during the life of symbiosis with blue green algae (Nostoc anabaena).They are the potential source of nitrogen especially for wet land rice (Table 4). The contribution of nitrogen from Azolla spp. to wet land rice has been found to be maximum when incorporated into the soil as green manure (Galal, 1997). The benefit of growing azolla as a biofertilizer for both $\mathrm{N}$ and $\mathrm{K}$ is its usefulness as human feed and it is also used as a mosquito repellent. An increase in the yield of paddy ranging from $9-39 \%$ has been obtained in the field experiment when Azolla was incorporated in the soil (Singh, 1977).

\section{Cyanobacteria}

$\mathrm{N}_{2}$ fixing Cyanobacteria are most wide spread $\mathrm{N}_{2}$ fixers on earth. Cyanobacteria or blue green algae are the 
Table 3. Effect of Azotobacter on crop yield.

\begin{tabular}{lclc}
\hline Crop & $\begin{array}{c}\text { Increase in yield over yields obtained } \\
\text { with chemical fertilizers (\%) }\end{array}$ & Crop & $\begin{array}{c}\text { Increase in yield over yield obtained with } \\
\text { chemical fertilizers (\%) }\end{array}$ \\
\hline Food grains & & Other & \\
Wheat & $8-10$ & Potato & 13 \\
Rice & 5 & Carrot & 16 \\
Maize & $15-20$ & Cauliflower & 40 \\
Sorghum & $15-20$ & Tomato & $2-24$ \\
& & Cotton & $7-27$ \\
& & Sugarcane & $9-24$ \\
\hline
\end{tabular}

Table 4. Azolla spp. which can be used as biofertilizer.

\begin{tabular}{ll}
\hline Azolla spp. & Reference \\
\hline A. pinnata & Singh and Srivastava, 1984 \\
A. mexicana & Thanh and Hang, 1988 \\
A. filiculoides & Singh and Srivastava, 1984 \\
A. rubra & Stergianou and Fowler, 1990 \\
A. niloticaa & Stergianou and Fowler, 1990 \\
A. caroliniana & Thanh and Hand, 1988 \\
A.microphylla & Stergianou and Fowler, 1990 \\
\hline
\end{tabular}

diverse group of prokaryotes. The activities of nitrogenfixing organisms provide an important source of nitrogen to the marine eco system (Gonzalez et al., 2005). They also grow and fix nitrogen in terrestrial environment, from rain forest to desert (Peter et al., 2002). Cyanobacteria are able to survive in the extreme environment and have ability to fix nitrogen because of the capacity to fix nitrogen; they are used as a bio fertilizer. In addition to contributing $\mathrm{N}$, the Cyanobacteria add organic matter, secrete growth promoting substance like auxin, vitamins, mobilise insoluble phosphate and improve physical and chemical nature of the soil. Cyanobacteria act as a supplement to the $\mathrm{N}$ fertilizers contributing up to $30 \mathrm{~kg} \mathrm{~N} /$ ha. It increases the crop yield between 5-25\%.

\section{Mass multiplication of Azolla}

For mass multiplication of Azolla, microplots $\left(20 \mathrm{~m}^{2}\right)$ are prepared in the nurseries in which sufficient water (5-10 $\mathrm{cm}$ ) is added. For profuse growth of Azolla 4-20 kg $\mathrm{P}_{2} \mathrm{O}_{5}$ is amended. Optimum pH 8.0 and temperature of 14$30^{\circ} \mathrm{C}$ should be maintained. Finally, microplots are inoculated with fresh Azolla. An insecticide (Furadon) is used to check the insect's attack. After 3 weeks, the mat of Azolla is ready for harvest and the same microplots are inoculated with fresh azolla to repeat the cultivation. Azolla mat is harvested and dried to use as green manure.

\section{Mass multiplication of Cyanobacteria}

The following methods are used for mass cultivation:

a) Cemented tank method

b) Shallow metal trough method

c) Polythene lined pit method

d) Field method

i) Prepare the cemented tank, shallow trays of iron sheets are polythene lined pits in an open area. Width of tanks or pits should not be more than $1.5 \mathrm{~m}$. This will facilitate the proper handling of culture.

ii) Transfer $2-3 \mathrm{~kg}$ soil and add $100 \mathrm{~g}$ superphosphate. Water the pit to about $10 \mathrm{~cm}$ height, Mix lime to adjust the $\mathrm{pH}$. Add $2 \mathrm{ml}$ of insecticides to protect the culture from mosquitoes. Mix well and allow to settle down soil particles.

iii) When water become clear, sprinkle $100 \mathrm{~g}$ starter culture on the surface of water.

iv) When temperature remains around $35-40^{\circ} \mathrm{C}$ during summer, optimum growth of Cyanobacteria is achieved. The water level is always maintained at about $10 \mathrm{~cm}$ during the period.

v) After drying, the algal mass is separated from the soil that form flaskes. Then it is collected, powdered and packed in the polythene bag and supplied to the farmers after sealing the packets.

vi) The algal flakes can be used as starter inoculums again.

\section{Gluconacetobacter diazotrophicus}

G. diazotrophicus is a nitrogen-fixing, acetic acid bacterium first isolated from sugarcane plants. It belongs to phylum Proteobacteria (comprising Gram negative bacteria) section a-Proteobacteria, order Rhodospirillales and family Acetobacteraceae. Currently, this family contains three nitrogen-fixing genera, comprising of seven species, namely Acetobacter nitrogenifigens, Gluconacetobacter kombuchae, Gluconacetobacter johannae Gluconacetobacter azotocaptans, G. 
Table 5. Biofertilizers which are used against crops.

\begin{tabular}{|c|c|c|}
\hline Biofertilizer & Recommended crop & Fertilizer saving \\
\hline Azolla pinnata (fresh) & Low land rice & $30-50$ kg N \\
\hline Azolla pinnata (dry) & Wheat, potato, tobacco & $30-50 \mathrm{~kg} \mathrm{~N}$ \\
\hline BGA & Low land rice & $30-50 \mathrm{~kg} \mathrm{~N}$ \\
\hline Azotobacter chroococcum & Pearlmillet,sorghum, rajma, sugarcane, maize, potato, pigeonpea, onion, cotton & $20-40 \mathrm{~kg} \mathrm{~N}$ \\
\hline Azospirillum lipoferum & Pearlmillet, fingermillet, paddy, sorghum, maize, tobacco, onion & $20-40 \mathrm{~kg} \mathrm{~N}$ \\
\hline Acetobacter diazotrophicus & Sugarcane & $100 \mathrm{~kg} \mathrm{~N}$ \\
\hline Rhizobium spp & Pigeonpea, chickpea, greengram & $30-50 \mathrm{~kg} \mathrm{~N}$ \\
\hline Bacillus circulans & Cow pea & $20-50 \mathrm{~kg} \mathrm{P} \mathrm{O}_{5}$ \\
\hline Bacillus brevis & Sorghum, wheat, pearlmillet & $20-50 \mathrm{~kg} \mathrm{P}_{2} \mathrm{O}_{5}$ \\
\hline Bacillus congulans & Sorghum, cowpea, pearlmillet, groundnut & $20-50 \mathrm{~kg} \mathrm{P}_{2} \mathrm{O}_{5}$ \\
\hline
\end{tabular}

diazotrophicus, Swaminathania salitolerans and Acetobacter peroxydans.

\section{Rhizobium}

Rhizobium belongs to family Rhizobiaceae, it is symbiotic in nature, it fixes $50-100 \mathrm{~kg} / \mathrm{ha}$ nitrogen with legumes only. It includes the following genera: Rhizobium, Bradyrhizobium, Sinorhizobium, Azorhizobium, Mesorhizobium and Allorhizobium (Vance, 2001; Graham and Vance, 2000). It is useful for the pulse legumes like chickpea, red-gram, pea, lentil, black gram, etc., oil-seed legumes like soybean and groundnut and forage legumes like berseem and lucerne (Table 5). It colonizes the roots of specific legumes to form tumour like growths called root nodules, which acts as factories of ammonia production.

Rhizobium has ability to fix atmospheric nitrogen in symbiotic association with legumes and certain nonlegumes like Parasponia. Population of the Rhizobium population in the soil depends on the presence of legume crops in the field. In the absence of legumes, the population decreases.

\section{Frankia (N fixers)}

Frankia is the genus of N2-fixing actinomycetes (Benson and Silvester, 1993; Huss-Danell, 1997). These are also called actinorhizal plants and they are also used in land reclamation, for timber and fuel wood production, in mixed plantations, for windbreaks, (Schwencke and Carù, 2001). Frankia $\mathrm{N}_{2}$ fixation has been estimated to be similar to rhizobial symbioses (Torrey, 1978; Dawson, 1986; Dommergues, 1995).

\section{Plant growth promoting rhizobacteria}

Various bacteria can promote plant growth (Bashan, 1998).
Collectively, such bacteria are called plant-growthpromoting rhizobacteria (PGPR). These bacteria vary in their mechanism of plant growth promotion but generally influence growth via $P$ solubilization, nutrient uptake enhancement, or plant growth hormone production (Bashan et al., 1990; Okon and Labandera-Gonzalez, 1994; Goldstein et al., 1999; Richardson, 2001). Bertrand et al. (2000) showed that a rhizobacterium belonging to the genus Achromobacter could enhance root hair number and length in oilseed rape (Brassica napus).

\section{POTENTIAL ROLE OF BIOFERTILIZER IN AGRICULTURE}

The biofertilizers play an important role in improving the fertility of the soil (Kachroo and Razdan, 2006; Son et al., 2007). In addition, their application in soil improves the structure of the soil minimizes the sole use of chemical fertilizers. Under low land conditions, the application of BGA + Azospirillum proved significantly beneficial in improving LAl. Grain yield and harvest index also increase with use of biofertilizers. Inoculation with Azotobacter + Rhizobium + VAM gave the highest increase in straw and grain yield of wheat plants with rock phosphate as a $\mathrm{P}$ fertilizer. Azolla is inexpensive, economical, friendly, which provide benefit in terms of carbon and nitrogen enrichment of soil (Kaushik and Prassana, 1989). Some commercially available biofertilizers are also used for the crop (Table 6). Raj (2007) recorded that microorganisms (B. subtilis, Thiobacillus thioxidans and Saccharomyces sp.) can be used as bio-fertilizers for solubilization of fixed micronutrients like zinc. Soybean plants, like many other legumes can fix atmospheric nitrogen symbiotically and about 80 to $90 \%$ nitrogen demand could be supplied by soybean through symbiosis (Bieranvand et al., 2003). Bio-control, a modern approach of disease management can play a significant role in agriculture (Tverdyukev et al., 1994; Hoffmann-Hergarten et al., 1998; Yang-Xiu Juan et al., 2000; Sharon et al., 2001; Senthilkumar and 
Table 6. Commercially available biofertilizer and their manufacture, beneficial crop and associated microorganisms.

\begin{tabular}{|c|c|c|c|}
\hline Product & Manufacture's name & Microbe used & Benefical crop \\
\hline Nitragin TM & Nitragin Sales Corpn.Wisconsin, 53209 & Rhizobium & Soyabean \\
\hline Rhizocote & Coated Seed Ltd, Nelson, New Zealand & Rhizobium & Legumes \\
\hline Nodosit & Uniob Chemiques S.A. Belgium & Rhizobium & Legumes \\
\hline Rhizonit & Phlylaxia Allami Budapest, Hungary & Rhizobium & Legumes \\
\hline Nitrazina & Wytwornia Walcz Poland & Azotobacter & Cereals and vegetables \\
\hline N-germ & Laboratoire de Microbiologie, France & BGA & Rice \\
\hline $\begin{array}{l}\text { Tropical } \\
\text { inoculants }\end{array}$ & Tropical inoculants & Azotobacter & Rice and wheat \\
\hline Nodulaid & $\begin{array}{l}\text { Brisbane, Queensland Agricultural Lab. } \\
\text { New South Wales, UK }\end{array}$ & Rhizobium & Legume \\
\hline Azotobacterin & Tashkent laboratories Moscow & Azotobacter & Vegetable and cereals. \\
\hline Nodion & $\begin{array}{l}\text { Indian Organic Chems. Ltd. Mahew Mahal, } \\
\text { Bombay }\end{array}$ & Rhizobium & Legumes \\
\hline Azoteeka & Bacifil, 25 Nawal Kishore Rd.Lucknow & Azotobacter & Cereals \\
\hline Agro-teeka & $\begin{array}{l}\text { National Fertilizers and Chemicals 11, Ind } \\
\text { Area-II, Ramdarbar, Chandigarh }\end{array}$ & Azotobacter & $\begin{array}{l}\text { Wheat, rice, maize, tea, } \\
\text { sugarcane, potato. }\end{array}$ \\
\hline Rhizoteeka & Microbes India,87.Lenin Savabe, Calcutta & Rhizobium & Legumes \\
\hline Nitrogeron & Root Nodne Pvt. Ltd. Australia. & Rhizobium & Legumes \\
\hline
\end{tabular}

Rajendran, 2004; Li-Bin et al., 2005; Hossain et al., 2009). Trichoderma based BAU-biofungicide has been found promising to control root knot diseases of French bean (Rahman, 2005). Use of antagonist bacteria like Rhizobium and Bradyrhizobium also has significant effect in controlling root knot of mungbean (Khan et al., 2006). Growth, yield and quality parameters of certain plants significantly increased with biofertilizers containing bacterial nitrogen fixer, phosphate and potassium solubilizing bacteria and microbial strains of some bacteria (Youssef and Eissa, 2014).

\section{Constraints in the use of the biofertilizer}

1. Unavailability of suitable strain: Due to the lack of the availability specific strain it is one of the major constraint in the production of the biofertilizer. Based on the fact that selective strain have ability to survive both in the broth and the inoculants carrier.

2. Unavailability of suitable carrier: If suitable carrier is not available it is difficult to maintain the shelf life of the biofertilizer. As per the suitability, the order is peat, lignite, charcoal, FYM, soil, rice husk. Peat of good quality is rarely found in India. Good quality carriers have a good moisture holding capacity, free from toxic substances.

3. Lack of awareness among farmers: Farmers of India are not aware of the biofertilizers, their usefulness in increasing crop yields.

4. Inadequate and inexperienced staff: This is because the unskilled and the inadequate staff farmers are not given proper instruction about the application. The production of biofertilizers in the country is 10,000 $\mathrm{mt} / \mathrm{annum}$ and the production capacity is 18,000 $\mathrm{mt} / \mathrm{annum}$. Average annual consumption of biofertilizers in the country is about $64 \mathrm{~g} / \mathrm{ha}$.

\section{Limitation of biofertilizer}

1. Biofertilizers never mix with the chemical fertilizers.

2. Biofertilizers are never applied with the fungicides, plant ash at a same time.

3. Biofertilizers are never exposed to direct sunlight.

4. Stored at room temperature not below 0 and $35^{\circ} \mathrm{C}$.

\section{CONCLUSION}

Biofertilizers are becoming increasingly popular in many countries and for many crops. Biofertilizers are fertilizers containing living microorganisms, which increase microbial activity in the soil. Often, organic food is included to help the microbes get established. In India soil fertility is diminishing gradually due to soil erosions, loss of nutrition, accumulation of toxic elements, water logging and unbalanced nutrient compensation. Organic manure and bio fertilizers are the alternate sources to meet the nutrient requirement of crops. biofertilizers, benefiting the crops are Azotobacter, Azosprillium, Phosphobacter and Rhizobacter which are very important. The role of biofertilizer in agricultural production is of great importance. Inoculation of nitrogen fixing bacteria with biofertilizer increases the phosphorus level that influences the sunflower seed oil content and the proportion of fatty acids 
(unsaturated/saturated fatty acids ratio). Biofertilizers can also make plant resistant to adverse environmental stresses. Control of root-knot disease of soybean caused by Meloidogyne javanica may be explored through use of BAU-Biofungicide and BINA-Biofertilizer for eco-friendly management of this nemic disease avoiding chemical nematicides. The proper application and use of biofertilizers will not only have an impact on sustainable agriculture's economic development but it will also contribute to a sustainable ecosystem and the holistic well-being.

\section{Conflict of Interests}

The author(s) have not declared any conflict of interests.

\section{REFERENCES}

Andrew JW, Jonathan D, Andrew R, Lei S, Katsaridou NN, Mikhail S, Rodionov AD (2007). Living without Fur: the subtlety and complexity of iron-responsive gene regulation in the symbiotic bacterium Rhizobium and other a-proteobacteria. Biometals 20:501-511.

Arun KS (2007). Bio-fertilizers for sustainable agriculture. Mechanism of P solubilization. Sixth edition, Agribios publishers, Jodhpur, India. pp.196-197.

Ateia EM, Osman YAH, Meawad AEA (2009). Effect of organic fertilization on yield and active constituents of Thymus vulgaris $L$. under North Sinai Conditions. Res. J. Agric. Biol. Sci. 5(4):555-565.

Bashan Y, Harrison SK, Whitmoyer RE (1990). Enhanced growth of wheat and soybean plant inoculated with Azopirillum brasilense is not necessary due to general enhancement of mineral uptake. Appl. Environ. Microbiol. 56:769-775.

Bashan Y, Puente ME, Myrold DD, Toledo G (1998). In vitro transfer of fixed nitrogen from diazotrophic filamentous cyanobacteria to black mangrove seedlings. FEMS Microbiol. Ecol. 26:165-170.

Benson DR, Silvester WB (1993). Biology of Frankia strains, actinomycete symbionts of actinorhizal plants. Microbiol. Rev. 57:293-319.

Bertrand H, Plassard C, Pinochet X, Touraine B, Normand P, CleyetMarel JC (2000). Stimulation of the ionic transport system in Brassica napus by a plant growth-promoting rhizobacterium (Achromobacter sp.). Can. J. Microbiol. 46:229-236.

Bieranvand NP, Rastin NS, Afrideh H, Saghed N (2003). An evaluation of the $\mathrm{N}$ fixation capacity of some Bradyrhizobium japonicum strains for soybean cultivars. Iran. J. Agric. Sci. 34(1):97-104.

Boraste A (2009). Biofertilizers: A novel tool for agriculture. Int. J. Microbiol. Res.1(2):23-31.

Dawson JO (1986). Actinorhizal plants: Their use in forestry and agriculture. Outlook Agric. 15:202-208.

Dommergues YR (1995). Nitrogen fixation by trees in relation to soil nitrogen economy. Fertil. Res. 42:215-230.

Doroshenko EV, Boulygina ES, Spiridonova EM, Tourova TP, Kravchenko IK (2007). Isolation and characterization of nitrogenfixing bacteria of the genus Azospirillum from the soil of a sphagnum peat bog. Microbiol. 76: 93-101.

Ezz El-Din AA, Hendawy SF (2010). Effect of dry yeast and compost tea on growth and oil content of Borago officinalis plant. Res. J. Agric. Biol. Sci. 6:424-430.

Galal YGM (1997). Estimation of nitrogen fixation in an Ilzolla-rice association using the nitrogen-15 isotope dilution technique. Biol. Fertil. Soils 24:76-80.

Gaur AC (1990). Phosphate solublizing microorganisms as Bio fertilizer. Omega Scientific Publisher, New Delhi. p. 176.

Gharib FA, Moussa LA, Massoud ON (2008). Effect of compost and biofertilizers on growth, yieldand essential oil of sweet marjoram (Majorana hortensis) plant. Int. J. Agric. Biol. 10:381-387.
Goldstein AH, Braverman K, Osorio N (1999). Evidence for mutualism between a plant growing in a phosphate-limited desert environment and a mineral phosphate solubilizing (MPS) rhizobacterium. FEMS Microbiol. Ecol. 30:295-300.

Gonzalez LJB, Rodelas C, Pozo V, Salmeron MV, Mart nez, Salmeron $\checkmark$ (2005). Liberation of amino acids by heterotrophic nitrogen fixing bacteria. Amino Acids 28:363-367.

Graham PH, Vance CP (2000). Nitrogen fixation in perspective: An overview of research and extension needs. Field Crops Res. 65:93106

Hoffmann-Hergarten S, Gulati MK, Sikora RA (1998). Yield response and biological control of Meloidogyne incognita on lettuce and tomato with rhizobacteria. Zeitschrift fur Pflanzenkrankheiten und Pflanzenschutz 105(4):349-358.

Hossain MA, Mahbub M, Khanam N, Hossain MS, Islam MM (2009). Effect of Bio-agents on growth and root-knot (Meloidogyne javanica) disease of soybean. J. Agrofor. Environ. 3(1):77-80.

Huss-Danell K (1997). Actinorhizal symbioses and their N2 fixation. New Phytol. 136:375-405

Ismail EG, Walid WM, Salah K, Fadia ES (2014). Effect of manure and bio-fertilizers on growth, yield, silymarin content, and protein expression profile of Silybum marianum. Adv. Agric. Biol. 1(1):36-44.

Kachroo D, Razdan R (2006). Growth, nutrient uptake and yield of wheat (Triticum aestivum) as influenced by biofertilizers and nitrogen. Indian J. Agron. 51(1):37-39.

Kaushik BD, Prassana R (1989). Status of biological nitrogen fixation by cyanobacteria and Azolla. in Biological Nitrogen Fixation Research Status in India: 1889-1989, edited by K R Dadarwal and K S Yadav. Society of Plant Physiologist and Biochemists New Delhi. pp. 141208.

Khan A, Zaki MJ, Tariq M (2006). Seed treatment with nematicidal Rhizobium species for the suppression of Meloidogyne javanica root infection on mungbean. Int. J. Biol. Biotechnol. 3(3):575-578.

Khan AA, Jilani G, Akhtar MS (2009). Phosphorus solublising bacteria :occurance, mechanisms and their role in crop production. J. Agric. Biol. Sci.1:48-58

Kundu BS, Nehra K, Yadav R (2009). Biodiversity of phosphate solublising bacteria in the rhizosphere of chickpea mustard and wheat grown in the different regions of Haryana. Ind. J. Microbiol. 49:120-127.

Leithy S, Gaballah MS, Gomaa AM (2009). Associative impact of bioand organic fertilizers ongeranium plants grown under saline conditions. Int. J. Acad. Res 1(1):17-23.

Li-Bin, Xie-Guanlin, Soad A, Goosemans J. (2005). Suppression of Meloidogyne javanica by antagonistic and plant growth promoting rhizobacteria. J. Zhejiang Univ. Sci. 6B (6):496-501.

Mahdi SS, Hassan GI, Samoon SA, Rather HA, Dar SA, Zehra B (2010). Bio-fertilizers in organic agriculture. J. Phytol. 2(10):42-54.

Mahmoud LY (2009). Using some organic components and organic fertilization for Ocimum basilicum production M.Sc. Thesis, Faculty of Agriculture Ain Shames University, Egypt.fortuitum complex. Clin. Microbiol. Infect. 9(4):327-331.

Mishra P, Dash D (2014). Rejuvenation of Biofertilizer for Sustainable Agriculture and Economic Development. Consilience: The Journal of Sustainable Development 11(1):41-61.

Nahas E (1996). Factor determining rock phosphate solublization by microorganisms isolated from the soil. World. J Microb. Biotechnol 12:18-23.

Nghia NH, Gyurjan (1987). Problems and perspectives in establishment of nitrogen - fixing symbioses and endosymbioses. Endocyt. C. Res. 4:131-141.

Odame H (1997). Biofertilizer in Kenya: Research, production and extension dilemmas. Biotechnol. Dev. Monit. 30:2023.

Okon Y (1985). Azospirillum as a potential inoculant for agriculture. Trends Biotechnol. 3(9):223-228.

Okon Y, Labandera-Gonzalez CA (1994). Agronomic applications of Azospirillum: An evaluation of 20 years worldwide field inoculation. Soil Biol. Biochem. 26:1591-1601.

Pabby A, Prasanna R, Singh PK (2004). Biological significance of Azolla and its utilization in agriculture. Proc. Indian Natl. Sci. Acad. B 70(3)299-333.

Peter VM, Cassman K, Cleveland C, Crews T, Christopher BF, Grimm BN, 
Howarth WR, Marinov R, Martinelli L, Rastetter B, Sprent IJ (2002). Towards an ecological understanding of biological nitrogen fixation. Biogeochemistry 57:1-45.

Peters S (2002). Mycorrhiza 101. Reforestation Technologies International, Salinas,CA .Singh 1979 Use of azolla in rice production in India. In; Nitrogen and Rice. pp. 407-418

Peters S (2002). Mycorrhiza 101. Reforestation Technologies International, Salinas, CA.

Raghuwanshi R (2012). Opportunities and challenges to sustainable agriculture in India, NEBIO 3(2):78-86.

Rahman M (2005). Effect of BAU-Biofungicide and nematicide Curaterr against root-knot of French bean. M.Sc. Thesis, Department of Plant Pathology, Bangladesh Agricultural University, Mymensingh.

Raj SA (2007). Bio-fertilizers for micronutrients. Biofertilizer Newsletter (July). pp. 8-10.

Rawia EA, Nemat MA, Hamouda HA (2009). Evaluate effectiveness of bio and mineral fertilization on the growth parameters and marketable cut flowers of Matthiola incana L. Am. Eurasian J. Agric. Environ. Sci. 5: 509-518.

Richardson AE (2001). Prospects for using soil microorganisms to improve the acquisition of phosphorus by plants. Aust. J. Plant Physiol. 28:897-906.

Schwencke J, Carù M (2001). Advances in actinorhizal symbiosis: Host plant-Frankia interactions, biology, and applications in arid land reclamation: A review. Arid Land Res. Manage. 15:285-327.

Senthilkumar T, Rajendran G (2004). Bio-control agents for the management of disease complex involving root-knot nematode, Meloidogyne incognita and Fusarium moniliforme on grapevine (Vitis vinifera). Indian J. Nematol. 34(1):49-51.

Sharon E, Bar EM, Chet I, Herrera EA, Kleifeld O, Spiegel Y (2001). Biological control of the root-knot nematode Meloidogyne javanica by Trichoderma harzianum. Phytopathology 91(7):687-963.

Singh (1977). Multiplication and utilization of fern Azolla containing nitrogen fixing algal symbiont as green manure in rice cultivation. Rizo 46:642-644.
Singh A, Srivastava ON (1984). Effect of different soil pH on growth of Azolla pinnata R. Brown. Geobios $3: 123-125$.

Singh T, Ghosh TK, Tyagi MK, Duhan JS (1999). Survival of Rhizobia and level of contamination in charcoal and lignite. Ann. Biol. 15(2):155-158.

Son TN, Thu VV, Duong VC, Hiraoka H (2007). Effect of organic and bio-fertilizers on soybean and rice cropping system. Japan International Research Center for Agricultural Sciences, Tsukuba, Ibaraki, Japan.

Stergianou KK, Fowler K (1990). Chromosome number and taxonomic implication in fern genus Azolla. Plant Syst. Evol. 173:233-239.

Thanh LD, Hand DT (1988). Chromosome no in genus Azolla; in Proc $14^{\text {th }}$ Intl. Cong. Genetics, Toronto, Canada.

Torrey JG (1978). Nitrogen fixation by actinomycete-nodulated angiosperms. Bioscience 28: 586-592.

Tverdyukev AP, Nikonov PV, Yuslichenko NP. (1994). Trichoderma. Rev. P1. Pathology 73 (4): 237.

Vance CP (2001). Symbiotic nitrogen fixation and phosphorus acquisition. Plant nutrition in a world of declining renewable sources. Plant Physiol. 127: 390- 397.

Yang-Xiu Juan, He-Yuxian, Chen-Furu, Zhengliang (2000). Isolation and selection of eggmasses of Meloidogyne spp. in Fujiana province. Fujiana J. Agric. Sci. 15(1):12-15.

Youssef MMA, Eissa MFM (2014). Biofertilizers and their role in management of plant parasitic nematodes. A review. E3 J. Biotechnol. Pharm. Res. 5(1):1-6. 